\title{
The potential anti-androgenic effect of agricultural pesticides used in the Western Cape: In vitro investigation of mixture effects
}

\author{
E Archer ${ }^{1 *}$ and JH van Wyk ${ }^{1}$ \\ 'Department of Botany and Zoology, Faculty Natural Science, University of Stellenbosch, Private Bag X1, Matieland, 7602, Stellenbosch, South Africa
}

\begin{abstract}
Although it is known that environmental chemicals can affect the oestrogenic system, far less attention has been paid to chemicals interacting with the androgen receptor (AR). Pesticides, particularly fungicides, have been shown to competitively bind or affect expression of the AR in an inhibiting manner. Few studies have addressed anti-androgenic effects of agrochemical use in South Africa. The aim of this study was to screen for the ability of commonly-used pesticides (mostly fungicides) in Western Cape agricultural areas to alter the binding of an androgen (DHT) to the human AR (hAR) using a recombinant yeast androgen screen (YAS), and also to test the additivity mixture interaction hypothesis when commonly-used pesticides with similar modes of action (MOAs) are exposed in mixture. Fungicides vinclozolin, folpet, procymidone, dimethomorph, fenarimol, mancozeb, and the insecticide chlorpyrifos, all independently antagonised the binding of the androgen dihydrotestosterone (DHT) to the AR in a dose-dependent manner. The fungicide mancozeb was found to be the most potent anti-androgen in the assay. Binary, equimolar mixtures of the pesticides also antagonised the binding of DHT to the $\mathrm{AR}$, but at lower $\mathrm{IC}_{50}$ concentration potencies relative to their individual counterparts. The mixtures of the majority of the selected pesticides did not conform to the expected additive mixture interaction. Only the mixture between dimethomorph and mancozeb showed an additive mixture response at $\mathrm{IC}_{50}$ concentrations, and, therefore, revealed a more severe AR antagonistic effect compared to their individual counterparts. This study confirmed that pesticides regularly used in agriculture inhibit the binding of androgens to the $\mathrm{AR}$, but when in mixture do not always conform to the predictive addition mixture response model. Also, high relative potencies of individual chemicals in the assay were suppressed when combined with less potent chemicals, showing that the potent chemicals may not be granted access to bind with the AR when exposed in mixture.
\end{abstract}

Keywords: androgen receptor, anti-androgen, fungicides, mixtures

\section{INTRODUCTION}

Several natural and man-made compounds have been shown to modulate endocrine activity in vertebrates (Heath and Claassen, 1999; Urbatzka et al., 2007a; Blake et al., 2010). Compounds acting in this way are collectively referred to as endocrine-disrupting contaminants (EDCs). Although the endocrine modulation may be subtle in cases, several of these EDCs have been shown to adversely disrupt the gonadal endocrine system of non-target organisms, potentially resulting in altered reproductive fitness, and may eventually show effects at a population level (Blake et al., 2010). Chemicals having endocrine-disrupting (ED) effects on the reproductive system can in general be categorised in 1 of 4 mode-of-action (MOA) groups (responses), namely, oestrogenic, anti-oestrogenic, androgenic or anti-androgenic (Behrends et al., 2010; Hoffmann and Kloas, 2010). The majority of EDC studies conducted to date have focused on EDCs modulating the oestrogenic response system in one way or the other (Sohoni and Sumpter, 1998; Urbatzka et al., 2007a \& 2007b; Kloas et al., 2009; Behrends et al., 2010). In contrast to the intensive research focus on manmade chemicals that potentially disrupt normal oestrogenic function, relatively few studies have addressed interaction with the androgenic endocrine systems, either from an agonistic or antagonistic perspective (Urbatzka et al., 2007a).

To whom all correspondence should be addressed

+2721 808 9356; e-mail: earcher@sun.ac.za

Received 11 October 2013; accepted in revised form 18 November 2014.
Contaminants having ED activity by an anti-androgenic MOA have been shown to disrupt mammalian foetal androgen synthesis, leading to incomplete masculinisation and reproductive organ development (Cristiansen et al., 2009). Chemicals modulating the androgen receptor (AR), resulting in an anti-androgenic response, have been shown to adversely affect male reproductive health, causing testicular dysgenesis syndrome, cryptorchydism, testicular cancer and altered semen quality (Skakkebæk et al., 2001; Kortenkamp and Faust, 2010). Although modulation of the androgenic system may not be limited to interaction with the AR, competitive binding at the AR level seems to have been the focus of most previous studies (Kelce et al., 1998; Ermler et al., 2010, 2011; Orton et al., 2011). Chemicals having AR antagonistic ED properties are of specific concern, as these contaminants can compete with androgens to bind to the AR, resulting in decreased transcription of target genes (Birkøj et al., 2004; Ermler et al., 2010, 2011). An example of a direct AR antagonist is flutamide, a clinical drug used to treat prostate cancer (Behrends et al., 2010; Hoffmann and Kloas, 2010). Several pesticides, such as the DDT metabolite, p,p'-DDE and vinclozolin, have been shown to mimic the MOA of flutamide (Kelce et al., 1994; Orton et al., 2011).

In agricultural practice, pesticides are seldom applied individually and farmers rarely keep to one specific compound (Boone, 2008). In South Africa alone, more than 300 registered fungicide trade products are available, made up of one or more active ingredients (DAFF, 2013). Water pollution (through runoff, spray drift and/or leeching) is one of the major exposure 
threats to aquatic wildlife, domesticated stock and human health (Heath and Claassen, 1999; Dabrowski et al., 2011). It is likely that water sources close to agricultural practices will be contaminated with a mixture of chemicals with varying concentrations (Feron and Groten, 2002; Boone, 2008; Blake et al., 2010; Kortenkamp and Faust, 2010; Hass et al., 2012).

Two of the major challenges in the study of EDCs are that these chemicals act mostly at low concentrations, far below their registered no-observed-effect-level (NOEL), and may persist in complex mixtures for long periods of time in aquatic systems. Apart from establishing the mode of action of an individual chemical, it is important to understand the interaction of chemicals when in a mixture. There are two dimensions to consider in mixture studies: firstly, characterising the broad effect of individual chemicals (androgenic, anti-androgenic, oestrogenic and anti-oestrogenic), and, secondly, to establish their specific mechanism of action (e.g. receptor binding, steroidogenesis modulation) (Woodruff et al., 2008). Previous studies have stated that EDCs having similar mechanisms of action (e.g. AR antagonism) will be expected to have an additive mixture response (e.g. elevated anti-androgenic activity) while EDCs having dissimilar mechanisms of action will be expected to have independent mixture responses (no increased or reduced endocrine activity) (Birkhøj et al., 2004; Blake et al., 2010; Ermler et al., 2011). However, there are few in-vitro studies reporting on the anti-androgenic effects of commonly-used pesticides in South African agriculture, alone or as mixtures. Disregarding the combined effects of EDCs may result in an underestimation of the potential environmental and health risk of pollutants in our water systems (Kortenkamp and Faust, 2010).

Several in-vitro assays have been proposed for inclusion in an ED screening and testing programme (Juberg et al., 2014) by the United States Environmental Protection Agency (USEPA). These assays serve as first-tier screens to identify the potential EDC activity and suggested MOA of man-made chemicals detected in the environment (Hecker et al., 2011). Although the recombinant yeast assay (using hAR) has not been included in the battery of first-tier tests suggested by the USEPA, the YAS has been recognised as an assay that it is a relatively inexpensive screening tool with a standardised protocol (Sohoni and Sumpter, 1998; De Jager et al., 2011; Kolle et al., 2011).

The aim of this study was to screen selected pesticides, mostly fungicides, which are commonly used in Western Cape agricultural areas of South Africa, for their ability to alter the binding of an androgen (DHT) to the human AR (hAR) using a recombinant yeast anti-androgen screen (anti-YAS). Also, we aimed to test the additivity hypothesis using the YAS when commonly-used pesticides with similar MOAs are exposed in mixture.

\section{MATERIALS AND METHODS}

\section{Recombinant yeast and test chemicals}

The yeast strain, Saccharomyces cerevisiae, transfected with the human androgen receptor (hAR) gene and a plasmid containing an androgen response element (ARE)-linked lac-Z gene, was obtained from the laboratory of Prof J Sumpter, Brunel University, UK. Test chemicals $5 \alpha$-androstan-17ß-ol-3-one (DHT, CAS No. 1521-18-6), flutamide (CAS No. 13311-84-7), vinclozolin (CAS No. 50471-44-8), folpet (CAS No. 613-04500-1), procymidone (CAS No. 32809-16-8), dimethomorph (CAS No. 613-102-00-0), flusilazole (CAS No. 85509-19-9),
1,10-(2,2- dichloroethene-1,1-diyl)bis(4-chlorobenzene) (p,p'-DDE, CAS No. 72-55-9), fenarimol (CAS No. 6016888-9), chlorpyrifos (CAS No. 2921-88-2) and mancozeb (CAS No. 8018-01-7) were all purchased from Sigma Aldrich (Taufkirchen, Germany). All medium components for the yeast assay were made up according to Sohoni and Sumpter (1998) and were obtained from Sigma Aldrich (Taufkirchen, Germany), except for the chlorophenolred- $\beta$-D galactopyranoside (CPRG), which was obtained from Roche Diagnostics (Mannheim, Germany). Absolute ethanol (99.8\% HPLC grade, Sigma) was used as solvent for the chemical solutions.

\section{Recombinant yeast anti-androgen screen (anti-YAS) procedure}

We followed the basic protocol described in Sohoni and Sumpter (1998), but with modifications for the yeast antiandrogen screen (anti-YAS) as described in later studies (Urbatzka et al., 2007b; Kolle et al., 2011). In brief, assay medium was prepared by adding $0.5 \mathrm{~m} \ell \mathrm{CPRG}$ to $50 \mathrm{~m} \ell$ of fresh growth medium. The medium was seeded with $4 \times 10^{7}$ yeast cells from a previously incubated 24 -h culture. To generate a standard curve of a positive control, a stock solution of DHT $(1 \mu \mathrm{M})$ dissolved in absolute ethanol was made up and serially diluted $(10 \mu \ell /$ well $)$ into a sterile 96 -well flat bottom assay plate with a low evaporation lid (Costar, 3370). Blank wells containing no ligands were supplemented with only absolute ethanol $(10 \mu \mathrm{l} /$ well $)$. Test chemicals were evaluated in the presence of DHT at a concentration of $6.25 \mathrm{nM}\left(\mathrm{EC}_{50}\right.$ from the DHT standard curve). All pesticides were tested for their ability to inhibit the agonistic action of the androgen spike. Stock solutions of test chemicals were made up at a concentration of $20 \mathrm{mM}$ in absolute ethanol and serially diluted in a sterile 96 -well flat bottom plate to obtain 12 concentration ranges of each test chemical (Greiner bio-one, 655161). Each diluted concentration was transferred to a sterile 96 -well flat bottom assay plate with a low evaporation lid (Costar, 3370) at $10 \mu \mathrm{l} /$ well along with the DHT $\left(\mathrm{EC}_{50}\right)$ spike. Assay medium was added $(200 \mu \mathrm{l} /$ well $)$ to give a final 1/20 dilution of the test chemicals in the assay. The pesticide dilutions were tested in duplicate in 2 separate plates and in 2 separate experiments. A colour change of the assay medium was observed after $48 \mathrm{~h}$ of incubation $\left(31^{\circ} \mathrm{C}\right)$; absorbance was measured at $570 \mathrm{~nm}$ (colour change) and $620 \mathrm{~nm}$ (turbidity and toxicity) using a plate reader (Thermo multiscan, type 355, Ascent, version 2.6, Thermo Labsystems). These measurements were used to calculate the final absorbance (corrected value) of each dose-response effect from each test compound using Eq. (1).

chemical absorbance $(570 \mathrm{~nm})$ Corrected value $=[$ chemical absorbance $(620 \mathrm{~nm})-$ blank absorbance $(620 \mathrm{~nm})]$

\section{Specificity of the YAS and anti-YAS}

As the goal was to use vinclozolin, a fungicide previously reported to be an AR antagonist, as our benchmark for other pesticides, we compared it to the pharmaceutical model AR anatagonist, flutamide. The specificity of DHT to bind to the $\mathrm{AR}$ in a dose-response manner was confirmed in the $\beta$-galactosidase response in the YAS assay (Fig. 1). Androgenic reactivity initiated at $1 \mathrm{nM}$ and $\mathrm{AR}$ binding continued to 


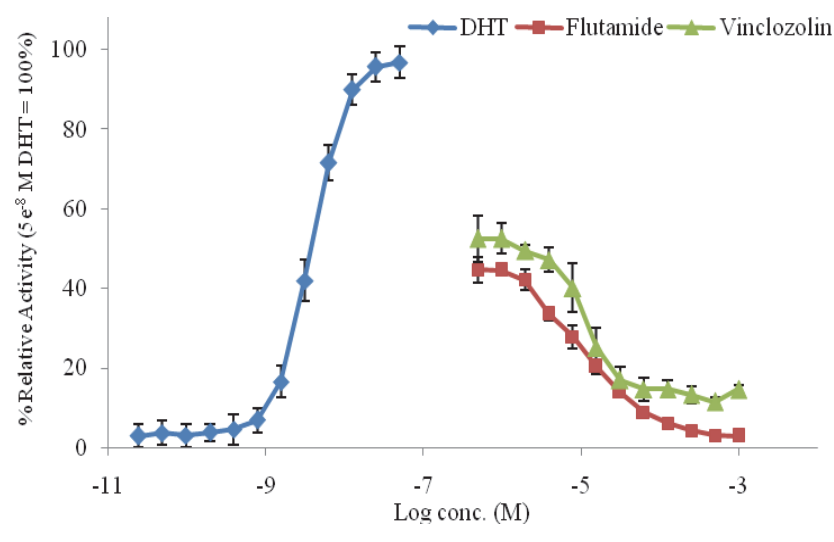

Figure 1

Sigmoidal standard curves of DHT, flutamide and vinclozolin in the yeast androgen and anti-androgen screen, respectively (YAS/anti-YAS). The series concentrations of flutamide and vinclozolin were spiked with 6.25 $n M D H T$. Values (means $\pm S E$ ) are expressed relative to the maximum logtransformed absorbance obtained from the DHT standard curve.

increase until the saturation level was reached at about $50 \mathrm{nM}$ DHT (Fig. 1). Total saturation of DHT-AR binding in the assay was reached at a DHT concentration of $5 \mathrm{e}^{-08} \mathrm{M}$ (Fig. 1). The AR binding reached $50 \%$ saturation $\left(\mathrm{EC}_{50}\right)$ at a $\mathrm{DHT}$ concentration of $6.25 \mathrm{nM}$. The inhibition of the androgenic spike $\left(\mathrm{EC}_{50} \mathrm{con}-\right.$ centration of DHT, $6.25 \mathrm{nM}$ ) response was confirmed through addition of both flutamide and vinclozolin (AR antagonists) (Fig. 1). Both vinclozolin and flutamide showed a similar AR antagonistic response and vinclozolin was subsequently used as the equivalent control for the selected test pesticides and mixtures thereof (Fig. 1). All test pesticides, mixtures and pharmaceuticals were also assessed for compound toxicity at an absorbance of $620 \mathrm{~nm}$, which indicates a loss of turbidity in yeast cells. None of the test compounds caused a loss of turbidity in the assays as compared to blank (unexposed) yeast cells (data not shown).

A vinclozolin dose-response curve was then used as the reference in each assay, to which the corrected absorbencies of the test chemicals were log-transformed and compared to the log-transformed corrected absorbancies of vinclozolin in the presence of $6.25 \mathrm{nM} \mathrm{DHT} \mathrm{(EC}{ }_{50}$ of DHT) using Eq. (2).

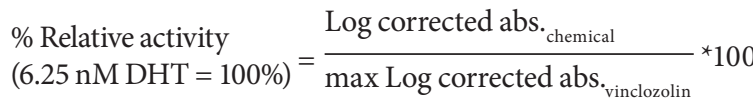

\section{Relative potency (RP) calculations}

The corrected absorbance of the test chemical dilutions was also used to calculate the $\mathrm{IC}_{50}$ (inhibition concentration at $50 \%$ relative to the vinclozolin control respectively) for each chemical. The relative potency (RP, Eq. (3)) was calculated from the $\mathrm{IC}_{50}$ for each pesticide.

$\mathrm{RP}(\%)=\frac{\mathrm{IC}_{50 \text {, vinclozolin }}}{\mathrm{IC}_{50 \text {, test chemical }}}{ } 100$

RP indicates the efficiency (\%) of the chemical to antagonise the AR binding of $6.25 \mathrm{nM}$ DHT relative to the AR antagonistic potency of the control (vinclozolin).

\section{Fungicide mixture assay calculations}

Following the individual chemical exposures, the pesticides were screened in the anti-YAS for simple mixture effects. Pesticides used for binary mixtures were added at equimolar concentrations (starting concentration; $1 \mathrm{mM}$ of each test compound) and tested in the same manner as with individual pesticides. Mancozeb was the only pesticide that was included in mixture at starting concentration of $1.95 \mu \mathrm{M}$ due to its high individual potency in the assay. The concentration giving $50 \%$ inhibition $\left(\mathrm{IC}_{50}\right.$ ) for each mixture was calculated and used to determine the isobole coefficient of the mixture as described by Birkhøj et al. (2004) (Eq. (4)).

$$
\text { Isobole coefficient }=\Sigma \frac{\mathrm{p} \cdot \mathrm{c}_{\mathrm{i} \text {,mix }}}{\mathrm{c}_{\mathrm{i}, \text { single }}}
$$

where:

$p$ is the partition of the single chemical in the mixture and $c_{i}$ is the concentration of $50 \%$ inhibition $\left(\mathrm{IC}_{50}\right)$ of the mixture or the single chemical.

The isobole coefficient estimates 3 mixture effect levels. A value equal to 1 could reflect an additive response; a value above 1 suggests an antagonistic response and a value below 1 suggests a synergistic response of the mixture.

Apart from measurement of the mixture interaction, we investigated the additivity null hypothesis which estimates the predicted $\mathrm{IC}_{50}$ concentrations of the pesticide mixtures assuming concentration addition (CA) or independent action (IA) (Ermler et al., 2011). For CA prediction, we used Eq. (5):

$\mathrm{CA}=\Sigma\left(\frac{\mathrm{p}_{\mathrm{i}}}{\mathrm{EC}_{\mathrm{i}}}\right)^{-1}$

TABLE 1

Test chemicals and their suggested mechanisms of ED action. Vinclozolin and DHT served as positive controls for the antiYAS and YAS, respectively. Pesticide active ingredients indicated with an asterisk $\left(^{*}\right)$ are anti-fungal pesticides.

\begin{tabular}{|l|l|l|l|}
\hline $\begin{array}{l}\text { Pesticide active } \\
\text { ingredient }\end{array}$ & Chemical class & Anti-androgenic mechanism of action & Reference \\
\hline Vinclozolin $^{*}$ & Dicarboximide & AR-binding antagonist & Kolle et al., 2011 \\
\hline Fenarimol & Pyrimidinyl carbinol & AR-binding antagonist & Vinggaard et al., 2005 \\
\hline Mancozeb $^{*}$ & Dithiocarbamate & AR-binding antagonist & Viswanath et al., 2010 \\
\hline Folpet $^{*}$ & Dicarboximide & $\begin{array}{l}\text { Expected AR-binding antagonist (same chemical group as } \\
\text { vinclozolin and procymidone) }\end{array}$ & n/a \\
\hline Dimethomorph $^{*}$ & Cinnamic acid & AR-binding antagonist & Orton et al., 2011 \\
\hline Procymidone & Dicarboximide & AR-binding antagonist & Ostby et al., 1999 \\
\hline Flusilazole & Triazole & Decrease androgen biosynthesis & Trösken et al., 2004 \\
\hline Chlorpyrifos & Organophosphate & Decreased testosterone biosynthesis, AR-binding antagonist & Viswanath et al., 2010 \\
\hline
\end{tabular}


where:

$p_{i}$ is the partition of the compound in the mixture;

$E C_{i}$ is the effect concentration of the $i^{\text {th }}$ compound which produces the same effect as in the mixture $\left(\mathrm{IC}_{50}\right)$.

For IA, we used Eq. (6) for the predicted $\mathrm{IC}_{50}$ of the mixture interactions.

$\mathrm{IA}=1-\Pi\left[1-E\left(C_{i}\right)\right]$

where $E\left(C_{i}\right)$ is the effect concentration of the $i^{\text {th }}$ compound which produces the same effect as in the mixture $\left(\mathrm{IC}_{50}\right)$.

\section{Statistical analyses}

The data were analysed using Statistica (version 10.0, StatSoft). Data were tested for homogeneity of variance and normal distribution. A one-way analysis of variance (ANOVA) was performed followed by pairwise comparisons between test compounds and control groups using Bonferroni's post-hoc test. Values obtained for $\mathrm{IC}_{50}$ concentrations, slope and lower parameters of the test compounds and mixtures were compared using a Student's t-test with differences from the control (vinclozolin exposure) indicating significant variances at $p<0.05$.

\section{RESULTS}

\section{Pesticide and mixture exposure in the anti-YAS}

A clear dose-response of all test pesticides on inhibition of binding of DHT to AR (AR antagonism) was observed between $0.3 \mu \mathrm{M}$ and $3 \mathrm{mM}$, with the exception of mancozeb, which had a dose-response range between $0.03 \mathrm{nM}$ and $32 \mu \mathrm{M}$ (Fig. 2). The dose-response curves provided $\mathrm{IC}_{50}$ concentrations of vinclozolin at $0.0049 \mathrm{mM}(1.4 \mathrm{mg} / \ell$; Table 3$)$. The carboximide fungicide folpet generated the same AR antagonistic

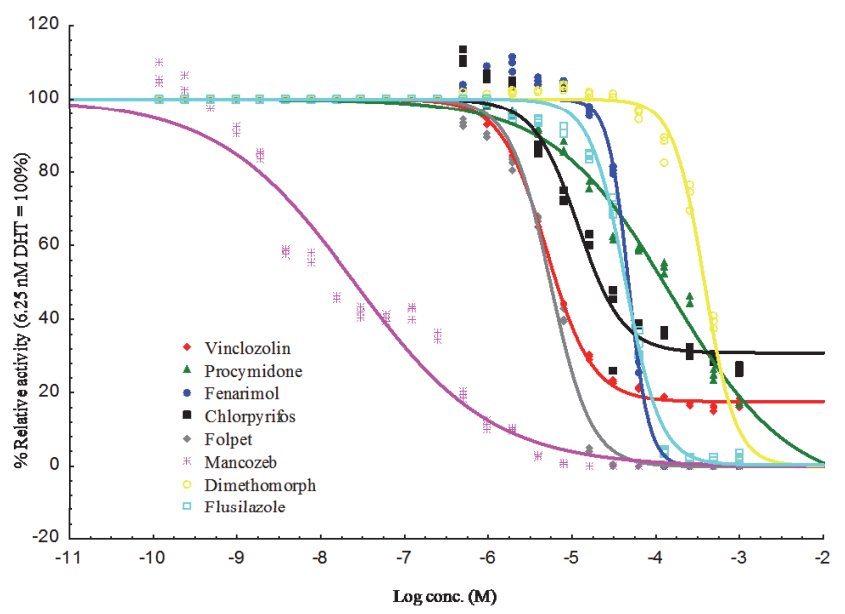

Figure 2

AR antagonistic dose-response of the test pesticides regularly used in agriculture in the Western Cape. Values are expressed as a percentage relative to the model AR antagonistic fungicide vinclozolin.

potency as vinclozolin (RP, 90\%; Table 2), with an $\mathrm{IC}_{50}$ concentration of $0.0055 \mathrm{mM}(1.6 \mathrm{mg} / \ell$, Table 3$)$. The $\mathrm{IC}_{50}$ values of the two carboximide fungicides did not vary significantly (t-test, $p>0.05$ ). The other caboximide fungicide, procymidone, had a weaker AR antagonistic potency than vinclozolin (RP, $3 \%$; Table 2) and an AR antagonistic $\mathrm{IC}_{50}$ concentration of 0.15 $\mathrm{mM}$ (42.6 mg/ $\ell$, Table 3). The dose-response curve of fenarimol provided an $\mathrm{IC}_{50}$ concentration of $0.0472 \mathrm{mM}(156 \mathrm{mg} / \ell$, Table 3 ), which is higher than vinclozolin, but still generated a high AR antagonistic potency relative to vinclozolin (Table 2).

Mancozeb was shown to be the most potent AR antagonist in the anti-YAS (Table 2; Fig. 2) with the $\mathrm{IC}_{50}$ of mancozeb being $2.5 \mathrm{e}^{-5} \mathrm{mM}$ in the assay $(0.007 \mathrm{mg} / \ell$, Table 3$)$.

\begin{tabular}{|c|c|c|c|c|c|}
\hline \multicolumn{6}{|c|}{$\begin{array}{l}\text { TABLE } 2 \\
\text { The } \mathrm{IC}_{50} \text { of test compounds in the YAAS, their isobole coefficients in mixture, and relative potency (RP) of the pesticides } \\
\text { to the control fungicide, vinclozolin. Isobole coefficients for the mixtures with a value }>1 \text { indicates antagonistic activity; } \\
\text { value }<1 \text { indicates synergism; value }=1 \text { indicates additivity. Predicted concentration addition (CA) and independent } \\
\text { action (IA) models are calculated by comparing the } \mathrm{IC}_{50} \text { concentrations of the individual pesticides generating the same } \mathrm{IC}_{50} \\
\text { concentration in the mixture. }\end{array}$} \\
\hline Pesticides & $\mathrm{IC}_{50}$ conc. (mM) & RP (\%) & & & \\
\hline Vinclozolin & $4.94 \mathrm{e}^{-03}$ & 100 & & & \\
\hline Procymidone & $1.53 \mathrm{e}^{-01}$ & 3 & & & \\
\hline Fenarimol & $4.72 \mathrm{E}^{-02}$ & 11 & & & \\
\hline Chlorpyrifos & $1.18 \mathrm{e}^{-02}$ & 42 & & & \\
\hline Folpet & $5.50 \mathrm{e}^{-03}$ & 90 & & & \\
\hline Mancozeb & $2.54 \mathrm{e}^{-05}$ & 19449 & & & \\
\hline Dimethomorph & $3.80 \mathrm{e}^{-01}$ & 1 & & & \\
\hline Flusilazole & $4.34 \mathrm{e}^{-02}$ & 11 & & & \\
\hline Pesticide mixture & $\mathrm{IC}_{50}$ conc. (mM) & $\mathrm{RP}(\%)$ & $\begin{array}{c}\text { Isobole } \\
\text { coefficient }\left(\mathrm{IC}_{50}\right)\end{array}$ & $\begin{array}{c}\text { Predicted } \\
\text { concentration } \\
\text { addition }\left(C A ; \mid C_{50}\right)\end{array}$ & $\begin{array}{c}\text { Predicted } \\
\text { independent } \\
\text { action }\left(I A ; I C_{50}\right)\end{array}$ \\
\hline Mancozeb + Dimethomorph & $4.65 \mathrm{e}^{-05}$ & 10624 & 0.92 & $5.07 \mathrm{e}^{-05}$ & $3.80 \mathrm{e}^{-01}$ \\
\hline Dimethomorph + Folpet & $2.49 \mathrm{e}^{-02}$ & 20 & 2.29 & $1.08 \mathrm{e}^{-02}$ & $3.83 \mathrm{e}^{-01}$ \\
\hline Vinclozolin + Folpet & $2.98 \mathrm{e}^{-02}$ & 17 & 5.72 & $5.21 \mathrm{e}^{-03}$ & $1.04 \mathrm{e}^{-02}$ \\
\hline Vinclozolin + Mancozeb & $7.70 \mathrm{e}^{-03}$ & 64 & 152.55 & $5.05 \mathrm{e}^{-05}$ & $4.97 \mathrm{e}^{-03}$ \\
\hline Vinclozolin + Fenarimol & $2.36 \mathrm{e}^{-02}$ & 21 & 2.63 & $8.95 \mathrm{e}^{-03}$ & $5.19 \mathrm{e}^{-02}$ \\
\hline Vinclozolin + Chlorpyrifos & $1.23 \mathrm{e}^{-01}$ & 4 & 17.59 & $6.96 \mathrm{e}^{-03}$ & $1.67 \mathrm{e}^{-02}$ \\
\hline
\end{tabular}




\begin{tabular}{|c|c|c|c|c|}
\hline \multicolumn{5}{|c|}{$\begin{array}{c}\text { TABLE } 3 \\
\begin{array}{c}\text { Measured IC } \\
\text { anti-YAS, compared to chemical analyses of pesticide concentrations } \\
\text { measured in environmental waters. }\end{array}\end{array}$} \\
\hline Pesticide & \begin{tabular}{|c|}
$\begin{array}{c}\text { Measured } \mathrm{IC}_{50} \\
\text { concentration } \\
(\mathrm{mg} / \mathrm{l})\end{array}$ \\
\end{tabular} & \begin{tabular}{|c|}
$\begin{array}{c}\text { Environmental } \\
\text { concentration } \\
(\mathrm{mg} / \mathrm{l})\end{array}$ \\
\end{tabular} & Country & Reference \\
\hline Vinclozolin & 1400.00 & 0.0024 & Germany & Oskam et al., 1993 \\
\hline Procymidone & 42.60 & 0.00041 & Australia & Oliver et al., 2012 \\
\hline Fenarimol & 156.00 & 0.01 & Australia & Oliver et al., 2012 \\
\hline Chlorpyrifos & 4.10 & 0.0019 & Australia & Oliver et al., 2012 \\
\hline Folpet & 1.60 & 0.000014 & Greece & Lambropoulou et al., 2000 \\
\hline Mancozeb & 0.007 & 0.039 & Italy & Fait et al., 2007 \\
\hline Dimethomorph & 147.40 & 0.00003 & USA & Reilly et al., 2012 \\
\hline Flusilazole & 13.60 & 0.0539 & USA & Deb et al., 2010 \\
\hline
\end{tabular}

Dimethomorph showed a low AR antagonistic potency relative to vinclozolin (Table 2) and was only anti-androgenic at higher concentrations than the other test compounds, with an $\mathrm{IC}_{50}$ concentration of $0.38 \mathrm{mM}$ (147.4 mg/ $\ell$, Table 3). Dimethomorph also generated a steep slope in the dose-dependent responses indicating a small concentration range of AR antagonistic activity (Fig. 2). Similar steep dose-dependent slopes for AR antagonistic activity were also recorded in exposures to the fungicides fenarimol and flusilazole (Fig. 2). Flusilazole showed lower AR antagonistic potency relative to vinclozolin, with an $\mathrm{IC}_{50}$ concentration of $0.043 \mathrm{mM}(13.6 \mathrm{mg} / \ell$, Table 3). Apart from the fungicides tested in the study, the insecticide chlorpyrifos had a fairly high $\mathrm{AR}$ antagonistic potency relative to vinclozolin (Table 2) and an $\mathrm{IC}_{50}$ concentration of $0.0118 \mathrm{mM}$ ( $4.1 \mathrm{mg} / \ell$, Table 3$)$. All observed test pesticide concentrations in the current study showed remarkably higher $\mathrm{IC}_{50}$ concentrations in the YAAS screen than other publications showing observed concentrations of the test pesticides in environmental waters (Table 3).

A dose-response concentration range between binary, equimolar mixtures of selected test pesticides was generated between $1 \mu \mathrm{M}$ and $1 \mathrm{mM}$ with the exception of the mixed-ratio mixture in the current study between mancozeb and dimethomorph, which ranged between $0.1 \mathrm{nM}$ and $32 \mu \mathrm{M}$ in the assay (Fig. 3). The binary mixtures did not follow the expected additive mixture response at $\mathrm{IC}_{50}$ concentrations (isobole coefficient $>1$, Table 2; Fig. 3) with the exception of a mixture between mancozeb and dimethomorph which generated an additive mixture response at $\mathrm{IC}_{50}$ concentrations (isobole coefficient $\approx 1$, Table 2 ; Fig. 3). The observed $\mathrm{IC}_{50}$ concentration of this mixture was also more closely related to the calculated predicted CA model than the IA model (Table 2). Although the other binary mixtures did not conform to either of the predicted CA or IA models, the isobole coefficients of the mixtures indicated that the mixtures did not follow an expected concentration addition interaction (Isobole coefficients $>1$; Table 2). The mixture also had a higher AR antagonistic potency relative to vinclozolin alone (Table 2). Binary mixtures of folpet and dimethomorph showed higher $\mathrm{AR}$ antagonistic potencies than dimethomorph alone, but weaker than folpet alone (Table 2) and therefore generated an antagonistic mixture response at $\mathrm{IC}_{50}$ concentrations (isobole coefficient $>1$, Table 2, Fig. 3). The observed $\mathrm{IC}_{50}$ concentrations of all other binary mixtures did not conform to the expected additive mixture response (isobole coefficient $>1$, Table 2; Fig. 3). A mixture between folpet and vinclozolin had an AR antagonistic potency of $17 \%$, which is less than the relative

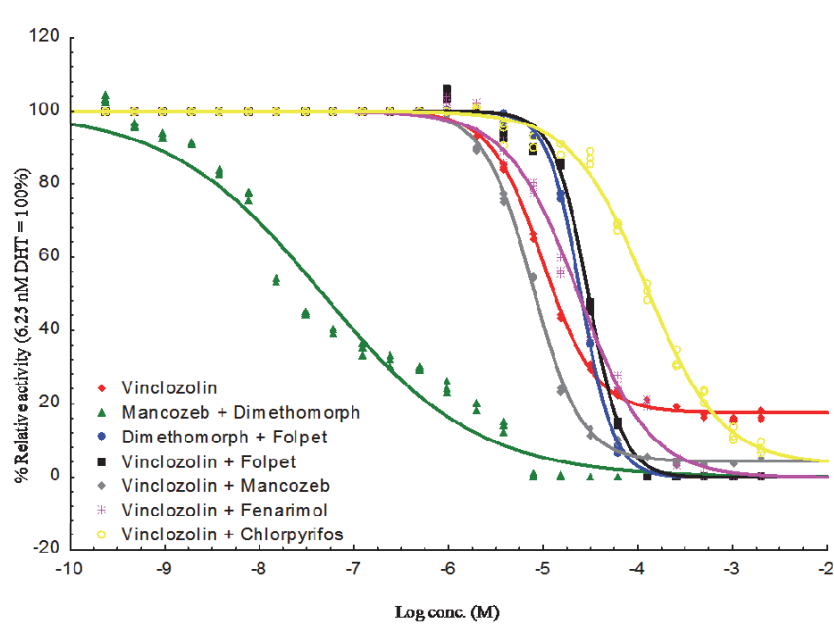

Figure 3

$A R$ antagonistic dose-response of equimolar binary mixtures of the test pesticides. Values are expressed as a percentage relative to the model $A R$ antagonistic control fungicide, vinclozolin.

potency of folpet alone (Table 2). Although the fungicide mancozeb was a potent AR antagonist in the assay, a mixture of vinclozolin and mancozeb generated an $\mathrm{IC}_{50}$ concentration closer to the $\mathrm{IC}_{50}$ of vinclozolin (Table 2; Fig. 3). The mixture therefore showed a non-additive mixture response (isobole coefficient $\gg$ 1, Table 2; Fig. 2) and was slightly less potent at antagonising AR binding than vinclozolin alone (Table 2). In the binary mixture of vinclozolin and chlorpyrifos, the mixture revealed a lower AR antagonistic potency relative to both vinclozolin and chlorpyrifos alone (Table 2) and also did not conform to the expected additivity mixture response at $\mathrm{IC}_{50}$ concentrations (isobole coefficient $>1$, Table 2; Fig. 2). This pesticide mixture was the least reactive in the anti-YAS.

\section{DISCUSSION}

In this study 6 fungicides and one insecticide, which are regularly used in agriculture, exerted anti-androgenic activity by decreasing the androgen response expected from the presence of DHT. Since many of these pesticides may occur in mixture in environmental waters, we investigated the additive null hypothesis (Christiansen et al., 2009; Ermler et al., 2011) and showed that this may not always apply. 
Vinclozolin has been extensively studied for its anti-androgenic properties, and are therefore included in most studies as a model AR antagonist (Kojima et al., 2004). The similar potency of this fungicide to flutamide has also been well-documented in both in-vitro and in-vivo studies (Hoffmann and Kloas, 2010; Kolle et al., 2011). In aquatic vertebrates, vinclozolin has been shown to modulate secondary sexual characteristic development and reproductive behaviour of male African clawed frogs, Xenopus laevis (Van Wyk et al., 2003; Hoffmann and Kloas, 2010). The other carboximide fungicides screened in the present study (procymidone and folpet) also revealed similar AR antagonistic properties. Procymidone has been shown elsewhere to cause an AR receptor-binding-dependent increase in luteinising hormone ( $\mathrm{LH})$ and testosterone levels in rats and mice (Crisp et al., 1998) and to increase the incidence of hypospadias in newborn rats (Ostby et al., 1999; Baskin et al., 2001). Folpet also proved to be a potent AR antagonist when screened using the anti-YAS. However, due to the limited information on folpet as an anti-androgenic EDC, future in-vitro and in-vivo research is needed to confirm its MOA and specific mechanism of action.

It is evident that information regarding the specific mechanism of endocrine action is also lacking for other fungicides. Not many studies have considered dimethomorph as an antiandrogenic EDC. Orton et al. (2011) reported that dimethomorph antagonised AR binding in both a yeast-based assay as well as a mammalian cell-based assay (MDA-kb2), but that there was a large divergence between inhibition concentrations in the two assays. Regardless of this, dimethomorph has been shown to have a high environmental equivalence ratio (ERR), which refers to its total exposure score relevant to its reported $\mathrm{IC}_{20}$ (Orton et al., 2011). Total exposure scores are calculated according to a pesticide's maximum food residue level, estimated daily dietary intake and frequency of detection in fruits and vegetables (Orton et al., 2011). If the ERR is calculated to be much greater than the chemical's $\mathrm{IC}_{20}$, the pesticide can be regarded as an environmentally-relevant pollutant (Orton et al., 2011). Such pesticides therefore need to be included in future toxicological and ED studies. Furthermore, the dithiocarbamate fungicide mancozeb was found to be the most potent AR antagonist in the present study. Although, mancozeb is largely known to act as a thyroid inhibitor (Cocco, 2002; Pickford, 2010), recent research investigated its reproductive toxicity potential (Joshi et al., 2005; Viswanath et al., 2010). Mancozeb has been shown to cause nipple retention in male rat pups (Hass et al., 2012). Exposure of mancozeb to Wistar rats reported lowered testis, epididymis and ventral prostate weights, as well as lowered sperm counts (Joshi et al., 2005). Results from the present study also confirm the anti-androgenic MOA of mancozeb through a mechanism of AR antagonism. However, more comprehensive research (on both in-vitro and in-vivo level) is needed to verify the fungicide mancozeb as an AR antagonistic EDC.

Apart from the fungicides tested in this study, the organophosphate insecticide chlorpyrifos is extensively used in agriculture and applied alongside fungicides. This insecticide has been reported to show anti-androgenic activity in mammalian and amphibian species (Kang et al., 2004; Viswanath et al., 2010; Bernabò et al., 2011). The present study confirms the anti-androgenic activity of chlorpyrifos with a dose-response activity similar to that of vinclozolin. Although chlorpyrifos may act as an anti-androgen, several lines of evidence also suggest that this pesticide may also disrupt the thyroid system (De Angelis et al., 2009), and therefore has the potential to act as both a reproductive and thyroid EDC. It is therefore clear that all of the test pesticides used in the current study may have multiple MOAs in endocrine systems if they are present in environmental waters.

It is known that pollutants from various point sources eventually end up in complex mixtures in freshwater systems (Blake et al., 2010). This has been confirmed, for example, in pulp and paper mill discharges containing androgenic and oestrogenic compounds (Blake et al., 2010), which combine with other pollutants from sources such as agricultural pesticides, and effluents from wastewater treatment plants (WWTPs). In the agricultural sector itself, compounds from different agricultural crops located near each other and treated with different pesticide types will eventually reach water catchments (Bollmohr and Schulz, 2009). In complex mixtures, these cocktails of chemicals may include contaminants that may or may not have similar MOAs in endocrine systems (Backhaus and Faust, 2012). For chemicals having the same MOA, it is mostly assumed that a dose-additive response will be the outcome (Boone, 2008; Christiansen et al., 2009; Ermler et al., 2011). Since all the individual pesticides included in this study showed a dose-dependent inhibition effect of DHT binding to the AR, an additive response was the default prediction. However, the binary mixtures of the test pesticides did not show a concentration addition interaction (as indicated by their isobole coefficients) and also correlated poorly with the calculated concentration addition (CA) and independent action (IA) models. This may partly be explained by the different physiochemical properties of the individual chemicals (as shown in Table 1), even though the individual chemicals all showed AR antagonism in the current study. Alternatively, only the mixed-ratio mixture exposure between dimethomorph and mancozeb did provide an additive mixture response. This may be ascribed to dimethomorph (a less potent AR antagonist), which might increase the AR antagonistic potency of mancozeb. Interestingly, commercial agricultural fungicides are available which consist of a mixture of dimethomorph and mancozeb (for example Acrobat WG, MZ; DAFF, 2013). In light of the findings of this study, further analyses are needed to investigate other commercial mixtures, where the active ingredients may have a larger probability to accumulate in freshwater systems.

It is evident in this study that chemical mixtures having similar MOAs will not always generate an additive mixture response. For example, the antagonistic mixture response between vinclozolin and chlorpyrifos, vinclozolin and folpet, and between vinclozolin and fenarimol in this study revealed that the mixtures were far less potent than either one of the individual chemicals. However, the binary mixture of vinclozolin and mancozeb raised a very interesting response, in which the inhibitory activity (capacity) of the vinclozolin/mancozeb mixture corresponded more to the vinclozolin inhibition response curve. These results suggest that the $\mathrm{AR}$ antagonistic potency of mancozeb was lowered when combined with vinclozolin, due to vinclozolin itself, which might have a higher affinity to bind to the. The non-additive response of the pesticide mixtures in this study is supported by other mixture studies. Equimolar mixtures of 4 parabens all revealed individual AR antagonism in a screen using Chinese hamster ovary (CHO) cells, but in mixture also had lower AR antagonistic properties than the predicted additivity model (Kjærstad et al., 2010). This was also a case in another study where mixtures of 10,11 and 16 oestrogenic pesticides were revealed to have weaker oestrogenic mixture responses than the expected additive response 
(Silva et al., 2011). However, a study by Ermler et al. (2011), investigating the AR antagonistic potential of 17 anti-androgens, showed that, despite varied structural features of the individual compounds, the CA concept provided a good mixture prediction for compounds having a similar MOA. In terms of the AR antagonistic potential of parabens, the results of a study by Ermler et al. (2011) were in contrast to those reported by Kjærstad et al. (2010), who showed deviation from the CA prediction. Ermler et al. (2011) suggested that their approach, using a mixed ratio design for mixture analyses, as opposed to the equimolar mixture ratio design used by Kjærstad et al. (2010), accounts for the variation in AR antagonistic potency by the different parabens. Clearly, the lack of conformation to the CA model in the present study needs further research to confirm the deviation from the CA prediction, as found in other studies.

The fate and presence of anti-androgenic pesticides has not been well investigated in environmental samples (Urbatzka et al., 2007b). The pesticides tested in this study have all been recorded to be used in South African agriculture and found in nearby river catchment systems (Dabrowski et al., 2002; Dalvie et al., 2003). To our knowledge, the present study is the first to evaluate their AR antagonistic potential alone and in mixture. Most gonadal ED research studies in South Africa have been concerned about oestrogenic activity of environmental contaminants (Van Wyk et al., 2005; Ansara-Ross et al., 2012). However, the present study confirms potential anti-androgenic activity in local aquatic environments. Due to the cross-reactivity of certain compounds to several gonadal endocrine systems (e.g. targeting both the ER and AR), it has been noted that some compounds regarded as oestrogenic EDCs may well be even more potent anti-androgenic EDCs (Sohoni and Sumpter, 1998). This phenomenon has also been observed in an environmental screening study in the United Kingdom (Jobling et al., 2009). Therefore, more research is needed to assess the situation in South African water systems receiving similar pollution types.

It is also clear from the literature that there are limited data available on the environmental monitoring of pesticides in surface waters (Jooste et al., 2008; Ansara-Ross et al., 2012). Several factors, including the pesticide's environmental fate, bio-availability and bioaccumulation/bio-concentration in a biotic system, as well as geographical conditions and climatic periods in which the pesticide is applied, might modulate the field potency of a chemical (Noyes et al., 2009; Dabrowski et al., 2011). This may also explain why the measured $\mathrm{IC}_{50}$ concentrations in the current study are far higher than levels found in environmental waters (Table 3). It is known that climatic conditions may alter the environmental fate, stability and behaviour of pesticides in water systems, such as causing increasing pesticide volatility, enhancing degradation time, or enhancing the wet deposition of pesticides in environmental waters (Noyes et al., 2009). We argue that temporal (seasonal) and spatial (different agricultural activities and river catchments) variation in environmental concentrations of pesticide pollutants may change the expected mixture interactions of freshwater pollutants and must therefore be considered in future studies.

In South Africa, Government has initiated the National Toxicity Monitoring Programme (NTMP) which focuses on identifying chemicals of interest which cause toxic effects on wildlife, with the aim of eventually isolating or phasing-out these toxic substances in inland water resources (Jooste et al., 2008). It is however evident that this programme does not propose to include EDC endpoints (Jooste et al., 2008; Ansara-Ross et al., 2012) even though contaminants (especially fungicides) present at low concentrations in the aquatic environment, as well as in treated water, may well be potent sources of antiandrogens. Although in-vitro studies pose several advantages in establishing the mechanism of ED of a chemical or mixture of chemicals, 1-cell assays serve as valuable first-tier screens. However, the use of in-vivo studies is still necessary to confirm ED effects in functional biological systems. We have suggested the importance of, and deviations from, the predicted additive model when exposing different concentrations of contaminants together. The finding that mixture predictions did not always apply when using equimolar mixtures needs to be further investigated, as this may complicate extrapolation of mixture results to environmental concerns. It is therefore evident that a more comprehensive screen of regularly used pesticides using a tiered approach is needed, which includes more in-vitro and in-vivo mixture investigations of presently-used pesticides (Ansara-Ross et al., 2012), using both equimolar and a mixed ratio design.

In conclusion, the present study confirmed the value of a recombinant yeast bioassay to screen for the specific mechanism of anti-androgenic action in locally-used agrichemicals (fungicides and insecticides) on a first-tier basis. Furthermore, we confirmed the AR antagonistic activity of commonly-used pesticides in South African agricultural practices and investigated the interaction of binary chemical mixtures. We also report that additivity predictions of EDC mixtures having a similar mechanism of anti-androgenic action may not always be accurate. The basis of the non-additivity of commonly used agricultural pesticide mixtures needs further study in order to eventually apply predictive risk assessment models to complex environmental mixtures.

\section{ACKNOWLEDGEMENTS}

We would like to thank the Water Research Commission of South Africa (WRC-SA) for funding this project, the University of Stellenbosch for the use of their facilities, Prof John Sumpter at Brunel University, United Kingdom, for supplying the recombinant yeast strain and Prof Martin Kidd at the University of Stellenbosch for statistical assistance.

\section{REFERENCES}

ANSARA-ROSS TM, WEPENER V, VAN DEN BRINK PJ and ROSS MJ (2012) Pesticides in South African fresh waters. Afr. J. Aquat. Sci. 37 (1) 1-16.

BACKHAUS T and FAUST M (2012) Predictive environmental risk assessment of chemical mixtures: a conceptual framework. Environ. Sci. Technol. 46 (5) 2564-2573.

BASKIN LS, HIMES K and COLBORN T (2001) Hypospadias and endocrine disruption: is there a connection? Environ. Health Perspect. 109 (11) 1175-1183.

BEHRENDS T, URBATZKA R, KRACKOW S, ELEPFANDT A and KLOAS W (2010) Mate calling behavior of male South African clawed frogs (Xenopus laevis) is suppressed by the antiandrogenic endocrine disrupting compound flutamide. Gen. Comp. Endocrinol. 168 (2) 269-274.

BERNABÒ I, GALLO L, SPERONE E, TRIPEPI S and BRUNELLI E (2011) Survival, development, and gonadal differentiation in Rana dalmatina chronically exposed to chlorpyrifos. J. Exp. Zool. Part A 315 (5) 314-327.

BIRKHØJ M, NELLEMANN C, JARFELT K, JACOBSEN H, ANDERSEN HR, DALGAARD M and VINGGAARD AM (2004) The combined antiandrogenic effects of five commonly used pesticides. Toxicol. Appl. Pharmacol. 201 (1) 10-20. 
BLAKE LS, MARTINOVIĆ D, GRAY JNR. E, WILSON VS, REGAL RR, VILLENEUVE DL and ANKLEY GT (2010) Characterization of the androgen-sensitive MDA-kb2 cell line for assessing complex environmental mixtures. Environ. Toxicol. Chem. 29 (6) 1367-1376.

BOLLMOHR S and SCHULZ R (2009) Seasonal changes of macroinvertebrate communities in a Western Cape river, South Africa, receiving nonpoint-source insecticide pollution. Environ. Toxicol. Chem. 28 (4) 809-817.

BOONE MD (2008) Examining the single and interactive effects of three insecticides on amphibian metamorphosis. Environ. Toxicol. Chem. 27 (7) 1561-1568.

CHRISTIANSEN S, SCHOLZE M, DALGAARD M, VINGGAARD AM, AXELSTAD M, KORTENKAMP A and HASS U (2009) Synergistic disruption of external male sex organ development by a mixture of four antiandrogens. Environ. Health Perspect. 117 (12) 1839-1846.

COCCO P (2002) On the rumors about the silent spring. Review of the scientific evidence linking occupational and environmental pesticide exposure to endocrine disruption health effects. Cadernos de Saude Publica 18 (2) 379-402.

CRISP TM, CLEGG ED, COOPER RL, WOOD R, ANDERSON DG, BAETCKE KR, HOFFMANN JL, MORROW MS, RODIER DJ, SCHAEFFER JE and co-authors (1998) Environmental endocrine disruption: an effects assessment and analysis. Environ. Health Perspect. 106 (1) 11-56.

DABROWSKI JM, PEALL SKC, REINECKE AJ, LEISS $M$ and SCHULZ R (2002) Runoff-related pesticide input into the Lourens River, South Africa: Basic data for exposure assessment and risk mitigation at the catchment scale. Water Air Soil Pollut. 135 (1-4) $265-283$.

DABROWSKI JM, SCHACHTSCHNEIDER K, ROSS TA, BOLLMOHR S and THWALA M (2011) Development of an indicator methodology to estimate the relative exposure and risk of pesticides in South African surface waters. WRC Report No. 1854/1/11. Water Research Commission, Pretoria.

DALVIE MA, CAIRNCROSS E, SOLOMON E and LONDON L (2003) Contamination of rural surface and ground water by endosulfan in farming areas of the Western Cape, South Africa. Environ. Health 2 (1) 1-15.

DE ANGELIS S, TASSINARI R, MARANGHI F, EUSEPI A, DI VIRGILIO A, CHIAROTTI F, RICCERI L, VENEROSI PESCIOLINI A, GILARDI E, MORACCI G, CALAMANDREI G, OLIVIERI A and MANTOVANI A (2009) Developmental exposure to chlorpyrifos induces alterations in thyroid and thyroid hormone levels without other toxicity signs in CD-1 mice. Toxicol. Sci. 108 (2) 311-319.

DEB D, ENGEL BA, HARBOR J, HAHN L, LIM KJ and ZHAI T (2010) Investigating potential water quality of fungicides used to combat soybean rust in Indiana. Water Air Soil Pollut. 207 (1-4) 273-288.

DE JAGER C, ANECK-HAHN NH, BARNHOORN IEJ, BORNMAN MS, PIETERS R, VAN WYK JH and VAN ZIJL C (2011) The compilation of a toolbox of bio-assays for detection of estrogenic activity in water. WRC Report No. 1816/1/10. Water Research Commission, Pretoria.

DAFF (DEPARTMENT OF AGRICULTURE, FORESTRY AND FISHERIES, SOUTH AFRICA) (2013). URL: http://www.nda. agric.za/doaDev/sideMenu/ActNo36 1947/AR/Fungicides.htm (Accessed 18 November 2014).

EKMAN DR, VILLENEUVE DL, TENG Q, RALSTON-HOOPER KL, MARTINOVIC-WEIGELT D, KAHL MD, JENSEN KM, DURHAN EJ, MAKYNEN EA, ANKLEY GT and co-author (2011) Use of gene expression, biochemical and metabolite profiles to enhance exposure and effects assessment of the model androgen $17 \beta$-trenbolone in fish. Environ. Toxicol. Chem. 30 (2) 319-329.

ERMLER S, SCHOLZE M and KORTENKAMP A (2011) The suitability of concentration addition for predicting the effects of multi-component mixtures of up to 17 anti-androgens with varied structural features in an in vitro AR antagonist assay. Toxicol. Appl. Pharmacol. 257 (2) 189-197.

ERMLER S, SCHOLZE M and KORTENKAMP A (2010) The sensitivity of the MDA-kb2 cell in vitro assay in detecting anti-androgenic chemicals - identification of sources of variability and estimation of statistical power. Toxicol. In Vitro 24 (6) 1845-1853.

FAIT G, NICELLI M, FRAGOULIS G, TREVISAN M and CAPRI E (2007) Reduction of point contamination sources of pesticide from a vineyard farm. Environ. Sci. Technol. 41 (9) 3302-3308.

FERON VJ and GROTEN JP (2002) Toxicological evaluation of chemical mixtures. Food Chem. Toxicol. 40 (6) 825-839.

HASS U, BOBERG J, CHRISTIANSEN S, JACOBSEN PR, VINGGAARD AM, TAXVIG C, POULSEN ME, HERRMANN SS, JENSEN BH, PETERSEN A, CLEMMENSEN LH and AXELSTAD $M$ (2012) Adverse effects on sexual development in rat offspring after low dose exposure to a mixture of endocrine disrupting pesticides. Reprod. Toxicol. 34 (2) 261-274.

HEATH RGM and CLAASSEN M (1999) An overview of the pesticide and metal levels present in populations of the larger indigenous fish species of selected South African rivers. WRC Report No. 428/1/99. Water Research Commission, Pretoria.

HECKER M, HOLLERT H, COOPER R, VINGGAARD AM, AKAHORI Y, MURPHY M, NELLEMANN C, HIGLEY E, NEWSTED J, LASKEY J and co-authors (2011) The OECD validation program of the H295R steroidogenesis assay: Phase 3. Final inter-laboratory validation study. Environ. Sci. Pollut. Res. 18 (3) 503-515.

HOFFMANN F and KLOAS W (2010) An environmentally relevant endocrine-disrupting antiandrogen, vinclozolin, affects calling behavior of male Xenopus laevis. Horm. Behav. 58 (4) 653-659.

JOBLING S, BURN RW, THORPE K, WILLIAMS R and TYLER C (2009) Statistical modeling suggests that antiandrogens in effluents from wastewater treatment works contribute to widespread sexual disruption in fish living in English rivers. Environ. Health Perspect. 117 (5) 797-802.

JOOSTE S, BOLLMOHR S and THWALA M (2008) National Toxicity Monitoring Program: Report on Phase 3: Pilot Implementation and Testing of the Design. Report No. N/0000/REQ1008. Resource Quality Services, Department of Water Affairs and Forestry, Pretoria, South Africa.

JOSHI SC, GULATI N and GAJRAJ A (2005) Evaluation of toxic impacts of mancozeb on testis in rats. Asian. J. Exp. Sci. 19 (1) 73-83.

JUBERG DR, BORGHOFF SJ, BECKER RA, CASEY W, HARTUNG T, HOLSAPPLE MP, MARTY MS, MIHAICH EM, VAN DER KRAAK G, WADE MG and co-authors (2014) Lessons learned, challenges, and opportunities: The U.S. Endocrine Disruptor Screening Program. Transatlantic Think Tank for Toxicology: Workshop Report. URL: http://dx.doi.org/10.14573/altex.1309171 (Accessed 18 November 2014).

KANG HG, JEONG SH, CHO JH, KIM DG, PARK JM and CHO MH (2004) Chlropyrifos-methyl shows anti-androgenic activity without estrogenic activity in rats. Toxicol 199 (2-3) 219-230.

KELCE WR, GRAY LE and WILSON EM (1998) Antiandrogens as environmental endocrine disruptors. Reprod. Fertil. Dev. 10 (1) 105-111.

KELCE WR, MONOSSON E, GAMCSIK MP, LAWS SC and GRAY JR. LE (1994) Environmental hormone disruptors: Evidence that vinclozolin developmental toxicity is mediated by antiandrogenic metabolites. Toxicol. Appl. Pharmacol. 126 (2) 276-285.

KJÆRSTAD MB, TAXVIG C, ANDERSEN HR and NELLEMANN $\mathrm{C}$ (2010) Mixture effects of endocrine disrupting compounds in vitro. Int. J. Androl. 33 (2) 425-433.

KLOAS W, URBATZKA R, OPITZ R, WÜRTZ S, BEHRENDS T, HERMELINK B, HOFMANN F, JAGNYTSCH O, KROUPOVA H, LORENZ C and co-authors (2009) Endocrine disruption in aquatic vertebrates. Trends Comp. Endocrinol. Neurobiol. 1163 187-200.

KOJIMA H, KATSURA E, TAKEUCHI S, NIIYAMA K and KOBAYASHI K (2004) Screening for estrogen and androgen receptor activities in 200 pesticides by in vitro reporter gene assays using Chinese hamster ovary cells. Environ. Health Perspect. 112 (5) 524-531.

KOLLE SN, MELCHING-KOLLMUSS S, KRENNRICH G, LANDSIEDEL R and VAN RAVENZWAAY B (2011) Assessment of combinations of antiandrogenic compounds vinclozolin and flutamide 
in a yeast based reporter assay. Reg. Toxicol. Pharmacol. 60 (3) 373-380.

KORTENKAMP A and FAUST M (2010) Combined exposures to anti-androgenic chemicals: Steps towards cumulative risk assessment. Int. J. Androl. 33 (2) 463-472.

LAMBROPOULOU DA, KONSTANTINOU IK and ALBANIS TA (2000) Determination of fungicides in natural waters using solidphase microextraction and gas chromatography coupled with electron-capture and mass spectrometric detection. J. Chromatogr. A 893 (1) 143-156.

LO S, KING I, ALLÉRA A and KLINGMÜLLER D (2007) Effects of various pesticides on human $5 \alpha$-reductase activity in prostate and LNCaP cells. Toxicol. In Vitro 21 (3) 502-508.

MORTHORST JE, HOLBECH H and BJERREGAARD P (2010) Trenbolone causes irreversible masculinization of zebrafish at environmentally relevant concentrations. Aquat. Toxicol. 98 (4) 336-343.

NOYES PD, MCELWEE MK, MILLER HD, CLARK BW, VAN TIEM LA, WALCOTT KC, ERWIN KN and LEVIN ED (2009) The toxicology of climate change: Environmental contaminants in a warming world. Environ. Int. 35 (6) 971-986.

OLIVER DP, KOOKANA RS, ANDERSON JS, COX JW, FLEMING N, WALLER N and SMITH L (2012) Off-site transport of pesticides from two horticultural land uses in the Mt. Lofty Ranges, South Australia. Agric. Water Manage. 106 (S1) 60-69.

ORTON F, ROSIVATZ E, SCHOLZE M and KORTENKAMP A (2011) Widely used pesticides with previously unknown endocrine activity revealed as in vitro antiandrogens. Environ. Health Perspect. 119 (6) 794-800.

OSKAM G, VAN, GENDEREN J, HOPMAN R, NOIJ THM, NOORDSIJ A and PUIJKER LM (1993) A general view of the problem, with special reference to the Dutch situation. Water Suppl. 11 (1) 1-17.

OSTBY J, KELCE WR, LAMBRIGHT C, WOLF CJ, MANN P and GRAY JR. LE (1999) The fungicide procymidone alters sexual differentiation in the male rat by acting as an androgen-receptor antagonist in vivo and in vitro. Toxicol. Ind. Health 15 (1-2) 80-93.

PICKFORD DB (2010) Screening chemicals for thyroid-disrupting activity: A critical comparison of mammalian and amphibian models. Crit. Rev. Toxicol. 40 (10) 845-892.

REILLY TJ, SMALLING KL, ORLANDO JL and KUIVILA KM (2012) Occurrence of boscalid and other selected fungicides in surface water and groundwater in three targeted use areas in the United States. Chemosphere 89 (3) 228-234.

SILVA E, RAJAPAKSE N, SCHOLZE M, BACKHAUS T, ERMLER $S$ and KORTENKAMP A (2011) Joint effects of heterogeneous estrogenic chemicals in the E-Screen: Exploring the applicability of concentration addition. Toxicol. Sci. 122 (2) 383-394.

SKAKKEBÆK NE, RAJPERT-DE MEYTS E and MAIN KM (2001) Testicular dysgenesis syndrome: An increasingly common developmental disorder with environmental aspects. Hum. Reprod. 16 (5) 972-978.

SOHONI P and SUMPTER JP (1998) Several environmental oestrogens are also anti-androgens. J. Endocrinol. 158 (3) 327-339.

TRÖSKEN EE, SCHOLZ K, LUTZ RW, VOLKEL W, ZARN JA and LUTZ WK (2004) Comparative assessment of the inhibition of recombinant human CYP19 (aromatase) by azoles used in agriculture and as drugs for humans. Endocr. Res. 30 (3) 387-94.

URBATZKA R, BOTTERO S, MANDICH A, LUTZ I and KLOAS W (2007a) Endocrine disrupters with (anti)estrogenic and (anti)androgenic modes of action affecting reproductive biology of Xenopus laevis: I. Effects on sex steroid levels and biomarker expression. Comp. Biochem. Physiol. Part C: Toxicol. Pharmacol. 144 (4) 310-318.

URBATZKA R, VAN CAUWENBERGE A, MAGGIONI S, VIGANÒ L, MANDICH A, BENFENATI E, LUTZ I and KLOAS W (2007b) Androgenic and antiandrogenic activities in water and sediment samples from the river Lambro, Italy, detected by yeast androgen screen and chemical analyses. Chemosphere 67 (6) 1080-1087.

VAN WYK JH, POOL EJ and LESLIE AJ (2003) The effects of antiandrogenic and estrogenic disrupting contaminants on breeding gland (nuptial pad) morphology, plasma testosterone levels, and plasma vitellogenin levels in male Xenopus laevis (African clawed frog). Arch. Environ. Contam. Toxicol. 44 (2) 247-256.

VAN WYK JH, POOL EJ, HURTER E and LESLIE AJ (2005) The development and validation of bioassays to detect estrogenic and antiandrogenic activity using selected wildlife species. WRC Report No. 926 \& 1253/1/05. Water Research Commission, Pretoria.

VINGGAARD AM, JACOBSEN H, METZDORFF SB, ANDERSEN HR and NELLEMANN C (2005) Antiandrogenic effects in shortterm in vivo studies of the fungicide fenarimol. Toxicology 207 (1) 21-34.

VISWANATH G, CHATTERJEE S, DABRAL S, NANGUNERI SR, DIVYA G and ROY P (2010) Anti-androgenic endocrine disrupting activities of chlorpyrifos and piperophos. J. Steroid Biochem. Mol. Biol. 120 (1) 22-29.

WOODRUFF TJ, ZEISE L, AXEIRAD DA, GUYTON KZ, JANSSEN S, MILLER M, MILLER GG, SCHWARTZ JM, ALEXEEFF G, ANDERSON H and co-authors (2008) Meeting report: Moving upstream - Evaluating adverse upstream end points for improved risk assessment and decision-making. Environ. Health Perspect. 116 (11) 1568-1575. 
http://dx.doi.org/10.4314/wsa.v41i1.16 Available on website http://www.wrc.org.za

ISSN 0378-4738 (Print) = Water SA Vol. 41 No. 1 January 2015 ISSN 1816-7950 (On-line) = Water SA Vol. 41 No. 1 January 2015 